\title{
PENGARUH KERJASAMA TIM TERHADAP KINERJA KARYAWAN DI PT LION SUPERINDO
}

\author{
Farhan Elang Ibrahim ${ }^{1}$, Tjipto Djuhartono ${ }^{2}$, Nur Sodik ${ }^{3}$ \\ Universitas Indraprasta Persatuan Guru Republik Indonesia \\ Email: farhanelang68@gmail.com ${ }^{1}$, tjiptodjuhartono@gmail.com² ${ }^{2}$ nur.sodik@unindra.ac.id ${ }^{3}$
}

\begin{abstract}
Purpose. This study aims to determine the effect of teamwork on employee performance at PT. Lion Superindo.

Methods. This research was conducted with the Associative method. The population of this study were all employees of PT. Lion Superindo Duren Tiga Branch as many as 47 employees with purposive sampling obtained a sample of 47 employees. The instrument used in the form of a questionnaire with 19 statements. Data analysis using simple linear regression.

Findings. There is a positive and significant effect of teamwork on the performance of employees of PT. Lion Superindo, these three things can be proven from the value of tcount $7.77>$ ttable 2.01. This indicates that the better the implementation of teamwork by the company, the performance of employees at PT. Lion Superindo.

Implication. The implication of the results of this study is that improving employee performance can be done by improving good and effective teamwork, such as increasing enthusiasm at work, reducing work conflicts, and improving relationships between groups.
\end{abstract}

Keywords. Teamwork, Employee Performance.

\begin{abstract}
ABSTRAK
Tujuan. Penelitian ini bertujuan untuk mengetahui pengaruh kerjasama tim terhadap kinerja karyawan di PT. Lion Superindo.

Metode. Penelitian ini dilakukan dengan metode Asosiatif. Populasi penelitian ini adalah seluruh karyawan PT. Lion Superindo Cabang Duren Tiga sebanyak 47 karyawan dengan sampling purposive diperoleh sampel sebanyak 47 karyawan. Instrumen yang digunakan berupa kuesioner sebanyak 19 pernyataan. Analisis data menggunakan regresi linier sederhana.
\end{abstract}

Hasil. Terdapat pengaruh positif dan signifikan kerjasama tim terhadap kinerja karyawan PT. Lion Superindo hal tersebut dapat dibuktikan dari nilai $t_{\text {hitung }} 7,77>t_{\text {tabel }} 2,01$. Hal tersebut menandakan bahwa semakin baik penerapan kerjasama tim yang dilakukan perusahaan maka akan semakin meningkat pula kinerja karyawan pada PT. Lion Superindo.

Implikasi. Implikasi dari hasil penelitian ini adalah bahwa untuk meningkatkan kinerja karyawan dapat dilakukan dengan perbaikan kerjasama tim yang baik dan efektif, seperti meningkatkan antusiasme dalam bekerja, mengurangi konflik kerja, serta memperbaiki hubungan antar kelompok.

Kata Kunci : Kerjasama Tim, Kinerja Karyawan. 


\section{Pendahuluan}

Salah satu tantangan yang dihadapi oleh pegawai di masa depan adalah untuk menciptakan suatu organisasi yang memiliki sumber daya manusia yang semakin handal. Sumber daya manusia yang berkualitas ditujukan kepada peningkatan kontribusi yang dapat diberikan oleh para pegawai dalam organisasi ke arah tercapainya tujuan organisasi. Tercapainya tujuan organisasi tidak hanya tergantung pada peralatan modern, sarana dan prasarana yang lengkap, tetapi justru lebih tergantung pada manusia yang melaksanakan pekerjaan tersebut. Keberhasilan suatu organisasi sangat dipengaruhi oleh kinerja individu pegawainya, (Nurhayati dan Suprapti, 2019:41).

PT. Lion Super Indo, adalah perusahaan yang bergerak di bidang ritel supermarket. Sampai dengan saat ini gerai super indo sudah tersebar di wilayah pulau Jawa dan Sumatera. Dengan kondisi jumlah gerai yang cukup banyak, super indo perlu memastikan kebutuhan komposisi karyawan di setiap gerai dapat tercukupi. Super indo selalu berusaha meningkatkan kualitas kinerja karyawan agar dapat memberikan pelayanan yang prima kepada pelanggan.

Setiap bulannya manajemen PT. Lion Super Indo Cabang Duren Tiga melakukan penilaian kepada semua karyawan, baik itu manajemen, dapur, dan karyawan service, kriteria penilaianya terdiri dari 15 aspek yaitu: kerapihan, 3S (senyum, salam, sapa), komunikasi, gesit, ketelitian, interaktif, kebersihan, keramahan, efektifitas, team work, motivator, inisiatif, responsive, efisiensi, dan akurasi.

Tabel 1. Penilaian Kinerja Karyawan PT. Lion Super Indo Cabang Duren Tiga Periode Agustus s/d Desember 2020

\begin{tabular}{|c|l|c|c|c|c|c|c|c|}
\hline \multirow{2}{*}{ No } & \multirow{2}{*}{ Kriteria } & \multirow{2}{*}{ Target } & \multicolumn{5}{|c|}{ Bulan } & \multirow{2}{*}{ Rata-Rata } \\
\cline { 3 - 8 } & & & Aug & Sept & Okt & Nov & Des & \\
\hline 1 & Kerapihan & 85 & 85 & 85 & 85 & 85 & 85 & 85 \\
\hline 2 & Senyum, Salam, Sapa & 85 & 85 & 85 & 85 & 85 & 85 & 85 \\
\hline 3 & Komunikasi & 85 & 80 & 80 & 80 & 80 & 80 & 80 \\
\hline 4 & Gesit & 85 & 80 & 80 & 75 & 80 & 75 & 78 \\
\hline 5 & Ketelitian & 85 & 80 & 75 & 80 & 75 & 80 & 78 \\
\hline 6 & Interaktif & 85 & 80 & 80 & 80 & 80 & 80 & 80 \\
\hline 7 & Kebersihan & 85 & 80 & 80 & 80 & 80 & 80 & 80 \\
\hline 8 & Keramahan & 85 & 80 & 80 & 75 & 75 & 75 & 77 \\
\hline 9 & Efektifitas & 85 & 80 & 80 & 80 & 80 & 75 & 79 \\
\hline 10 & Team Work & 85 & 80 & 80 & 80 & 80 & 80 & 80 \\
\hline 11 & Motivator & 85 & 80 & 80 & 80 & 80 & 80 & 80 \\
\hline 12 & Inisiatif & 85 & 80 & 80 & 80 & 77 & 70 & 77,4 \\
\hline 13 & Responsive & 85 & 80 & 80 & 80 & 80 & 75 & 79 \\
\hline 14 & Efesiensi & 85 & 80 & 80 & 80 & 75 & 75 & 78 \\
\hline 15 & Akurasi & 85 & 80 & 80 & 75 & 75 & 75 & 77 \\
\hline
\end{tabular}

Sumber : PT. Lion Super Indo Cabang Duren Tiga (2021)

Berdasarkan tabel 1 dari setiap divisi baik managerial, kasir dan juga service terdapat beberapa aspek yang masih di bawah batas minimal yang diterapkan oleh perusahaan yaitu rata-rata nilai 85 . Hal itu terlihat pada penilaian kinerja karyawan terdapat aspek komunikasi, gesit, ketelitian, interaktif, kebersihan, keramahan, efektifitas, team work, motivator, inisiatif, responsive, efisiensi, dan akurasi yang masih dibawah standar yang ditetapkan oleh perusahaan. Hanya aspek kerapihan dan $3 \mathrm{~S}$ (senyum, salam, sapa) yang memenuhi target.

Berdasarkan hasil observasi yang penulis lakukan terkait rendahnya kinerja karyawan di PT. Lion Super Indo Cabang Duren Tiga disebabkan oleh belum adanya kemauan karyawan untuk bekerja secara maksimal. Belum maksimalnya kinerja karyawan dilihat dari tingkat ketelitian untuk menyelesaikan suatu pekerjaan yang dihasilkan belum memuaskan seperti, kesalahan dalam penginputan data transaksi, adanya antrian yang panjang di kasir ketika pelanggan hendak membayar. Salah memberikan uang kembalian kepada pelanggan, kurang ramah dalam melayani, kerja sama antar karyawan yang belum berjalan dengan baik dan terkesan bekerja terlalu sendiri-sendiri, serta belum maksimalnya inisiatif karyawan dalam bekerja yang selalu menunggu perintah dari atasan. 
Pekerjaan organisasi tidak akan terlaksana jika para anggota organisasi atau perusahaan tidak bekerja sama secara selaras. Menurut Susanti, Widyani, Utami (2021:226), kerjasama tim adalah sistem perpaduan kerja suatu kelompok yang didukung oleh berbagai keahlian dengan kejelasan tujuan, dan juga didukung oleh kepemimpinan dan komunikasi untuk menghasilkan kinerja yang lebih tinggi daripada kinerja individu. Kerja sama kelompok sangat diperlukan guna meningkatkan efiseinsi kerja baik itu di dalam perusahaan, swasta maupun pemerintahan. Adapun masalah-masalah yang terjadi dalam kerjasama tim pada karyawan PT. Lion Super Indo Cabang Duren Tiga yang belum begitu maksimal, yaitu kurangnya interaksi di dalam kelompok, sering terjadinya perbedaan pendapat, serta adanya ketidak kompakkan kerjasama tim seperti: tidak mau saling membantu menyelesaikan pekerjaan, tidak merasa senasib sepenanggungan, anggota tim tidak saling menyukai, beban tidak dibagi untuk satu tujuan bersama, tidak saling mengerti, perbedaan pendapat, dan tidak mendukung satu sama lain. Masalah-masalah yang terjadi di lapangan tersebut mengakibatkan seringnya terjadi keterlambatan dalam melaksanakan pekerjaan akibatnya target penyelesaian tugas sulit untuk terealisasi. Jika perusahaan tidak memiliki kerja sama yang kuat antara divisi satu dengan divisi lainnya, maka hasil dari kerjanya tidak akan memuaskan dan tidak efisien (tepat waktu).

Berdasarkan pada uraian latar belakang penelitian diatas maka penulis tertarik untuk melakukan penelitian dengan mengambil judul, Pengaruh Kerjasama Tim Terhadap Kinerja Karyawan di PT. Lion Superindo.

\section{Kajian Pustaka dan Hipotesis}

Kerjasama Tim. Menurut Susanti, Widyani, dan Utami (2021:226), kerjasama tim adalah sistem perpaduan kerja suatu kelompok yang didukung oleh berbagai keahlian dengan kejelasan tujuan, dan juga didukung oleh kepemimpinan dan komunikasi untuk menghasilkan kinerja yang lebih tinggi daripada kinerja individu. Sedangkan Panggiki, Lumanauw, dan Lumintang (2017:3019) mendefinisikan kerjasama tim (teamwork) adalah bentuk kerja dalam kelompok yang harus diorganisasi dan dikelola dengan baik. Tim beranggotakan orang-orang yang memiliki keahlian yang berbeda-beda dan dikoordinasikan untuk bekerja sama dengan pimpinan. Terjadi saling ketergantungan yang kuat satu sama lain untuk mencapai sebuah tujuan atau menyelesaikan sebuah tugas.

Dari berbagai definisi diatas bisa diambil kesimpulan bahwa kerjasama tim adalah sekelompok orang dengan kemampuan, talenta, pengalaman dan latar belakang yang berbeda yang berkumpul bersama-sama untuk mencapai satu tujuan dalam satu atau lebih kegiatan. Adapun Sibarani (2018:19) menetapkan dimensi dan indikator kerjasama tim sebagai berikut:

1) Kerjasama

Kerjasama dilakukan oleh sebuah tim lebih efektif daripada kerja secara individual. Kontribusi tiap-tiap individu dapat menjadi sebuah kekuatan yang terintegrasi. Individu dikatakan bekerja sama jika upaya-upaya dari setiap individu tersebut secara sistematis terintegrasi untuk mencapai tujuan bersama. Semakin besar integrasinya semakin besar tingkat kerja samanya. Indikator-indikator kerja sama sebagai alat ukurnya sebagai berikut:

a) Tanggung jawab secara bersama-sama menyelesaikan pekerjaan, yaitu dengan pemberian tanggung jawab dapat tercipta kerjasama yang baik.

b) Saling berkontribusi, yaitu dengan saling berkontribusi baik tenaga maupun pikiran akan terciptanya kerjasama.

c) Pengerahan kemampuan secara maksimal, yaitu dengan mengerahkankemampuan masing-masing anggota tim secara maksimal, kerjasama akan lebih kuat dan berkualitas.

2) Kepercayaan

Kepercayaan adalah keyakinan bahwa seseorang sungguh-sungguh dengan apa yang dikatakan dan dilakukannya. Kerjasama tim yang berkinerja tinggi dicirikan oleh kepercayaan (trust) timbal balik yang tinggi di antara anggota-anggotanya. Artinya para anggota meyakini akan integritas, karakter dan kemampuan setiap anggotanya. Indikatorindikator kepercayaan, yaitu:

a) Kejujuran, yaitu dengan adanya kejujuran anggota tim akan menciptakan rasa saling percaya. 
b) Pemberian tugas, yaitu dengan pemberian tugas pada anggota tim berarti telah memberikan kepercayaan bahwa anggota tim mampu melaksanakannya.

c) Integritas, yaitu setiap anggota dianggap memiliki integritas atau bersikap sebenarnya (truthfulness) dalam bekerja.

3) Kekompakan

Kekompakan adalah tingkat solidaritas dan perasaan positif yang ada dalam diri seseorang terhadap kelompoknya. Indikator-indikator sebagai berikut:

a) Saling ketergantungan tugas, yaitu saling ketergantungan pada tugas menciptakan kekompakan.

b) Saling ketergantungan hasil, yaitu anggota tim merasa hasil yang dicapai bukanlah hasil secara individu, tetapi hasil kekompakan bersama dalam bekerja.

c) Komitmen yang tinggi, yaitu anggota tim dianggap memiliki komitmen yang tinggi pada tujuan yang akan dicapai tim.

Kinerja Karyawan. Menurut Hasibuan (2017:94), kinerja pegawai merupakan suatu hasil kerja yang dicapai seseorang dalam melaksanakan tugas-tugasnya yang dibebankan kepadanya yang didasarkan atas kecakapan, pengalaman dan kesungguhan serta waktu. Menurut Fahmi (2017:188) "Kinerja adalah hasil dari suatu proses yang mengacu dan diukur selama periode waktu tertentu berdasarkan ketentuan atau kesepakatan yang telah ditetapkan sebelumnya". Sedangkan menurut Mangkunegara (2017:9) menyatakan bahwa kinerja adalah hasil kerja secara kualitas dan kuantitas yang dapat dicapai oleh seorang pegawai dalam melaksanakan tugas sesuai dengan tanggung jawab yang diberikan kepadanya.

Berdasarkan beberapa teori di atas, dapat disimpulkan bahwa kinerja merupakan suatu istilah secara umum yang digunakan sebagian atau seluruh tindakan atau aktivitas dari suatu organisasi pada suatu periode dengan suatu referensi. Kinerja sebagai hasilkerja karyawan dilihat dari aspek kualitas, kuantitas, waktu kerja, dankerja sama untuk mencai tujuan yang sudah di tetapkan oleh organisasi. Kinerja adalah keluaran yang dihasilkan oleh fungsi-fungsi atau indikator-indikator suatu pekerjaan atau suatu profesi dalam waktu tertentu. Dimensi dan Indikator kinerja karyawan menurut Robbins dan Coutler (2016:263) adalah sebagai berikut:

1) Kualitas Kerja

Kualitas kerja diukur dari persepsi karyawan terhadap kualitas pekerjaan yang dihasilkan serta kesempurnaan tugas terhadap keterampilan dan kemampuan karyawan.

2) Kuantitas Kerja

Merupakan jumlah yang dihasilkan dinyatakan dalam istilah seperti jumlah unit, jumlah siklus aktivitas yang diselesaikan. Kuantitas yang diukur dari persepsi karyawan terhadap jumlah aktifitas yang ditugaskan beserta hasilnya.

3) Ketepatan Waktu

Tingkat suatu aktivitas diselesaikan pada awal waktu yang dinyatakan, dilihat dari sudut koordinasi dengan hasil output serta memaksimalkan waktu yang tersedia untuk aktivitas lain. Ketepatan waktu diukur dari persepsi pegawai terhadap suatu aktifitas yang diselesaikan dari awal waktu sampai menjadi output.

4) Efektivitas

Tingkat penggunaan sumber daya organisasi (tenaga, uang, teknologi, bahan baku) dimaksimalkan dengan maksud menaikan hasil dari setiap unit dalam penggunaan sumber daya. Efektifitas kerja diukur dari persepsi karyawan dalam menilai pemanfaatan waktu dalam menjalankan tugas, efektifitas menyelesaikan tugas yang dibebankan organisasi.

5) Kemandirian

Tingkat dimana karyawan dapat melakukan fungsi kerjanya tanpa meminta bantuan atau bimbingan dari orang lain. Kemandirian diukur dari persepsi karyawan dalam melakukan fungsi kerjanya masing-masing, sesuai dengan tanggung jawabnya. 


\begin{tabular}{|c|c|}
\hline $\begin{array}{l}\quad \text { Kerjasama Tim } \\
\text { 1. Kerjasama } \\
\text { 2. Kepercayaan } \\
\text { 3. Kekompakan } \\
\text { Sumber: Sibarani (2018:19) }\end{array}$ & $\begin{array}{l}\quad \text { Kinerja Karyawan } \\
\text { 1. Kualitas kerja } \\
\text { 2. Kuantitas kerja } \\
\text { 3. Ketepatan Waktu } \\
\text { 4. Efektivitas } \\
\text { 5. Kemandirian } \\
\text { Sumber: Robbins dan Coutler } \\
(2016: 263)\end{array}$ \\
\hline
\end{tabular}

Gambar 1. Model Penelitian

\section{Hipotesis}

Menurut Sugiyono (2017:134), "hipotesis merupakan jawaban sementara terhadap rumusan masalah, dimana rumusan penelitian telah dinyatakan dalam bentuk kalimat pernyataan". Dikatakan sementara karena jawaban yang diberikan baru didasarkan pada teori yang relevan, belum didasarkan pada fakta-fakta empiris yang diperoleh melalui pengumpulan data.

$\mathrm{H}_{0}=$ Tidak terdapat pengaruh positif dan signifikan kerjasama tim terhadap kinerja karyawan di PT. Lion Superindo.

$\mathrm{H}_{\mathrm{a}}=$ Terdapat pengaruh positif dan signifikan kerjasama tim terhadap kinerja karyawan di PT. Lion Superindo.

\section{Metode Penelitian}

Desain penelitian yang digunakan dalam penelitian ini adalah penelitian kuantitatif. Penelitian kuantitatif digunakan dalam penelitian ini, karena data yang menjadi objek dalam penelitian ini merupakan data-data kuantitatif yang berupa angka-angka yang dihasilkan dari skala likert (Sugiyono, 2017:13). Metode yang digunakan dengan metode Asosiatif. Menurut Sugiyono (2017:44) "metode asosiatif adalah penelitian yang bertujuan untuk mengetahui pengaruh atau hubungan antara dua variabel lebih".

Populasi dalam penelitian ini adalah seluruh Karyawan PT. Lion Superindo cabang Duren tiga yang berjumlah 47 orang. Dalam penelitian ini teknik sampling yang digunakan adalah sampling purposive. Teknik sampling purposive adalah teknik penentuan sampel dengan pertimbangkan tertentu (Sugiyono, 2017:79). Teknik ini digunakan agar mendapatkan sampel sesuai dengan tujuan penelitian, dimana sampel dipilih berdasarkan kriteria-kriteria tertentu. Adapun kriterianya adalah sebagai berikut:

1) Karyawan PT. Lion Superindo cabang Duren tiga bukan dari cabang lain.

2) Karyawan merupakan staff/karyawan PT. Lion Superindo cabang Duren tidak termasuk keamanan dan cleaning service (outsourcing).

3) Karyawan yang bekerja di PT. Lion Superindo cabang Duren tiga baik pria maupun wanita dengan rentang usia antara 20-51 tahun, dengan pertimbangan bahwa pada usia 20 tahun merupakan usia produktif manusia.

4) Bersedia memberikan jawaban atau pernyataan pada lembar kuesioner saat penyebaran kuesioner.

Dari hasil sampling purposive maka jumlah sampel yang digunakan dalam peneliian ini adalah berjumlah 47 orang responden. Metode analisis yang dilakukan dalam penelitian ini adalah dengan analisis regresi linier sederhana, koefisien korelasi, koefisien determinasi, dan uji hipotesis.

\section{Hasil Penelitian dan Pembahasan Uji Validitas}

Uji validitas berguna untuk mengetahui apakah ada pernyataan pada kuesioner yang harus diganti karena dianggap tidak relevan. Syarat uji validitas adalah Jika $r_{h i t u n g}>r_{\text {tabel }}$ maka valid dan Jika $\mathrm{r}_{\text {hitung }}<\mathrm{r}_{\text {tabel }}$ maka tidak valid. 
Tabel 2. Hasil pengujian Validitas

\begin{tabular}{|c|c|c|c|}
\hline Pernyataan & Nilai r $_{\text {hitung }}$ & Nilai $\mathbf{r}_{\text {tabel }}$ & Keterangan \\
\hline Kerjasama Tim & \multicolumn{5}{|l|}{} \\
\hline Pernyataan 1 & 0,892 & 0,287 & Valid \\
\hline Pernyataan 2 & 0,968 & 0,287 & Valid \\
\hline Pernyataan 3 & 0,977 & 0,287 & Valid \\
\hline Pernyataan 4 & 0,964 & 0,287 & Valid \\
\hline Pernyataan 5 & 0,762 & 0,287 & Valid \\
\hline Pernyataan 6 & 0,975 & 0,287 & Valid \\
\hline Pernyataan 7 & 0,990 & 0,287 & Valid \\
\hline Pernyataan 8 & 0,989 & 0,287 & Valid \\
\hline Pernyataan 9 & 0,948 & 0,287 & Valid \\
\hline Kinerja Karyawan & \multicolumn{5}{|l|}{} \\
\hline Pernyataan 1 & 0,976 & 0,287 & Valid \\
\hline Pernyataan 2 & 0,925 & 0,287 & Valid \\
\hline Pernyataan 3 & 0,938 & 0,287 & Valid \\
\hline Pernyataan 4 & 0,905 & 0,287 & Valid \\
\hline Pernyataan 5 & 0,972 & 0,287 & Valid \\
\hline Pernyataan 6 & 0,882 & 0,287 & Valid \\
\hline Pernyataan 7 & 0,651 & 0,287 & Valid \\
\hline Pernyataan 8 & 0,904 & 0,287 & Valid \\
\hline Pernyataan 9 & 0,855 & 0,287 & Valid \\
\hline Pernyataan 10 & 0,909 & 0,287 & \\
\hline
\end{tabular}

Sumber: Data diolah Excel (2021)

Berdasarkan hasil uji validitas tersebut maka dapat dijelaskan bahwa keseluruhan nilai $r_{\text {hitung }}$ lebih besar dari $r_{\text {tabel }} 0,287$ dengan demikian maka dapat disimpulkan bahwa semua item dalam pernyataan variabel kerjasama tim dan kinerja karyawan adalah valid. Sehingga tidak ada item pernyataan yang dihapus dan semua item pernyataan dapat digunakan pada keseluruhan model pengujian.

\section{Uji Reliabilitas}

Menurut Arikunto (2015:89), reliabilitas adalah suatu pengukuran yang menunjukkan stabilitas dan konsistensi dari suatu variabel yang mengukur suatu konsep untuk mengakses dari suatu pengukuran. Metode yang digunakan dalam penelitian ini untuk menghitung reliabilitas yaitu dengan menggunakan metode Cronbach Alpha.

Tabel 3. Hasil Uji Reliabilitas

\begin{tabular}{|c|l|c|c|c|}
\hline No & \multicolumn{1}{|c|}{ Variabel } & Cronbach Alpha & Nilai Kritis & Keputusan \\
\hline 1 & Kerjasama Tim & 0,982 & 0,60 & Reliabel \\
\hline 2 & Kinerja Karyawan & 0,968 & 0,60 & Reliabel \\
\hline
\end{tabular}

Sumber: Data diolah Excel (2021)

Berdasarkan tabel diatas dapat diketahui bahwa variabel kerjasama tim memiliki nilai cronbach alpha 0,982 >0,60 dan kinerja karyawan memiliki nilai cronbach alpha 0,968 >0,60. Dengan demikian, maka hasil uji reliabilitas terhadap variabel kerjasama tim dan kinerja karyawan adalah reliabel. Dengan kata lain bahwa seluruh pernyataan pada penelitian ini memiliki tingkat kehandalan yang baik dan dapat digunakan dalam analisis berikutnya.

\section{Regresi Linier Sederhana}

Regresi Linier Sederhana digunakan untuk memprediksi besaran nilai variable terikat yang dipengaruhi oleh satu variabel bebas. Persamaan Regresi Linier Sederhana dinyatakan dengan rumus sebagai berikut: $\mathrm{Y}=\mathrm{a}+\mathrm{bX}$

Untuk mencari konstanta, digunakan rumus 


$$
\begin{aligned}
& a=\frac{\left(\sum Y\right)\left(\sum x^{2}\right)-\left(\sum x\right)\left(\sum X Y\right)}{n\left(\sum x^{2}\right)-\left(\sum x\right)^{2}} \\
& a=\frac{(1653)(56866)-(1526)(58781)}{47(56866)-(1526)^{2}} \\
& a=\frac{93999498-89699806}{2672702-2328676} \\
& a=\frac{4299692}{344026} \\
& a=12,498
\end{aligned}
$$

Menghitung nilai Koefisien Regresi (b) digunakan rumus:

$\mathrm{b}=\frac{\mathrm{n}(\Sigma \mathrm{XY})-(\Sigma \mathrm{X})\left(\sum \mathrm{Y}\right)}{\mathrm{n} \Sigma \mathrm{X}^{2}-(\Sigma \mathrm{X})^{2}}$

$\mathrm{b}=\frac{47(58781)-(1526)(1653)}{47(56866)-(1526)^{2}}$

$\mathrm{b}=\frac{2762707-2522478}{2672701-2328676}$

$\mathrm{b}=\frac{240229}{344026}$

$\mathrm{b}=0,698$

Berdasarkan perhitungan diatas diperoleh koefisien persamaan regresi linier sederhana sebagai berikut: $\mathbf{Y}=\mathbf{1 2 , 4 9 8 + 0 , 6 9 8 X}$. Artinya nilai (a) atau konstanta sebesar 12,498 nilai ini menunjukan bahwa pada saat kerjasama tim (X) bernilai nol atau tidak meningkat, maka kinerja karyawan (Y) akan tetap bernilai 12,498 koefisien regresi nilai (b) sebesar 0,698 (positif) yaitu menunjukkan pengaruh yang searah yang artinya jika kerjasama tim ditingkatkan sebesar satu satuan maka akan meningkatkan kinerja karyawan sebesar 0,698 satuan.

\section{Koefisien Korelasi}

Korelasi menjelaskan tentang bagaimana tingkat keeratan hubungan suatu variabel independen dengan variabel dependen dalam suatu sistem korelasi ganda, setelah mengontrol atau mengendalikan variabel independen lainnya. Hasil perhitungan korelasi dengan cara manual sebagai berikut:

$$
\begin{aligned}
& \mathrm{r}_{\mathrm{xy}}=\frac{47(58781)-(1526)(1653)}{\sqrt{\left.\left\{47 \cdot(56866)-(2328676)^{2}\right\} 47 \cdot(64355)-(1653)^{2}\right\}}} \\
& \mathrm{r}_{\mathrm{xy}}=\frac{2762707-2522478}{\sqrt{(344026) \cdot(292276)}} \\
& \mathrm{r}_{\mathrm{xy}}=\frac{240229}{\sqrt{100550543176}} \\
& \mathrm{r}_{\mathrm{xy}}=\frac{240229}{317097,0564} \\
& \mathrm{r}_{\mathrm{xy}}=0,757
\end{aligned}
$$

Berdasarkan hasil perhitungan tersebut dapat diketahui bahwa nilai korelasi sebesar 0,757 masuk dalam interval 0,60 - 0,799 dengan tingkat hubungan yang kuat. Sehingga dapat dikatakan bahwa tingkat kekuatan hubungan kerjasama tim terhadap kinerja karyawan memiliki tingkat hubungan yang kuat. 


\section{Koefisien Determinasi}

Analisis koefisien determinasi digunakan untuk mengetahui seberapa besar kontribusi variabel independen mempengaruhi variabel dependen dan hasilnya dalam bentuk prosentase. Hasil perhitungan koefisien determinasi dengan rumus sebagai berikut :

$$
\begin{aligned}
\mathbf{K D} & =(\mathbf{r})^{\mathbf{2}} \times \mathbf{1 0 0 \%} \\
& =(0,757)^{2} \times 100 \% \\
& =57,30 \%
\end{aligned}
$$

Berdasarkan perhitungan tersebut diketahui nilai koefisien determinasi sebesar 57,30\% yang artinya variabel kerjasama tim memberikan kontribusi terhadap variabel kinerja karyawan sebesar 57,30\%. Sedangkan sisanya sebesar 42,70\% disebabkan oleh faktor lain yang tidak diteliti oleh penulis seperti : gaya kepemimpinan, lingkungan kerja, disiplin kerja, motivasi dan variabel lainnya.

\section{Uji Hipotesis}

Untuk mengetahui apakah kerjasama tim memiliki pengaruh dalam meningkatkan Kinerja Karyawan maka perlu dilakukan uji signifikansi dengan menggunakan rumus sebagai berikut:

$$
\begin{aligned}
& \mathrm{t}-\text { hitung }=\frac{\mathrm{r} \sqrt{\mathrm{n}-2}}{\sqrt{1-\mathrm{r}^{2}}} \\
& \mathrm{t}=\frac{0,757 \sqrt{47-2}}{\sqrt{1-0,757^{2}}} \\
& \mathrm{t}=\frac{0,757 \sqrt{45}}{\sqrt{1-0,573049}} \\
& \mathrm{t}=\frac{0,757 \mathrm{X} 6,7082}{0,653414876} \\
& \mathrm{t}=\frac{5,0781}{0,653414876} \\
& \mathrm{thitung}=7,77 \\
& t_{\text {tabel }}: \quad \mathrm{DK}=\mathrm{n}-2 \\
& t_{\text {tabel }}=2,01
\end{aligned}
$$

Berdasarkan perhitungan tersebut dapat diketahui bahwa nilai $t_{\text {hitung }} 7,77>t_{\text {tabel }} 2,01$. Sesuai dengan kriteria Jika $t_{\text {hitung }}>t_{\text {tabel }}$, maka $\mathrm{H}_{0}$ ditolak dan $\mathrm{H}_{\mathrm{a}}$ diterima, artinya terdapat pengaruh positif dan signifikan kerjasama tim terhadap kinerja karyawan Pada PT. Lion Superindo.

\section{Pembahasan}

Berdasarkan hasil pengujian statistik dapat diketahui bahwa terdapat pengaruh positif dan signifikan kerjasama tim terhadap kinerja karyawan Pada PT. Lion Superindo hal tersebut dapat dilihat dari persamaan regresi linier sederhana $Y=12,498+0,698 X$ Artinya nilai (a) atau konstanta sebesar 12,498 nilai ini menunjukan bahwa pada saat kerjasama tim (X) bernilai nol atau tidak meningkat, maka kinerja karyawan (Y) akan tetap bernilai 12,498 koefisien regresi nilai (b) sebesar 0,698 (positif) yaitu menunjukkan pengaruh yang searah yang artinya jika kerjasama tim ditingkatkan sebesar satu satuan maka akan meningkatkan kinerja karyawan sebesar 0,698 satuan. Nilai korelasi sebesar 0,757 yang artinya bahwa tingkat kekuatan hubungan kerjasama tim terhadap kinerja karyawan memiliki tingkat hubungan yang kuat. Nilai koefisien determinasi sebesar $57,30 \%$ yang artinya variabel kerjasama tim memberikan 
kontribusi terhadap variabel kinerja karyawan sebesar 57,30\%. Sedangkan sisanya sebesar $42,70 \%$ disebabkan oleh faktor lain yang tidak diteliti oleh penulis seperti : gaya kepemimpinan, lingkungan kerja, disiplin kerja, motivasi dan variabel lainnya. Serta nilai $t_{\text {hitung }}$ $7,77>t_{\text {tabel }} 2,01$. Sesuai dengan kriteria Jika thitung $>t_{\text {tabel }}$, maka $\mathrm{H}_{0}$ ditolak dan $\mathrm{H}_{\mathrm{a}}$ diterima, artinya terdapat pengaruh positif dan signifikan kerjasama tim terhadap kinerja karyawan Pada PT. Lion Superindo.

Hasil penelitian tersebut menunjukkan bahwa karyawan menyadari bahwa dengan kerjasam tim setiap orang dapat mencapai lebih banyak lagi hal yang ingin dicapai. Kerjasama Tim merupakan suatu kebiasaan yang dilakukan manusia untuk memenuhi pencapaian tujuan bersama, demikian juga hal ini terjadi pada perusahaan yang membagi-bagi kelompok untuk mencapai tujuan perusahaan dengan efektif. Performa seseorang akan lebih terlihat apabila dibandingkan langsung dengan pegawai lainnya di dalam tim Penilaian kerja ditunjukan untuk menilai kualitas dan kuantitas kerja para karyawan dengan membandingkan kemampuan pegawai pada rekan rekannya yang lain. Kerjasama tim (teamworks) akan menjadi bentuk organisasi, pekerjaan yang cocok untuk memperbaiki kinerja perusahaan.

Hasil penelitian ini didukung oleh penelitian Susanti, Widyani, dan Utami (2021), dimana hasil penelitian menunjukan bahwa Kerjasama tim berpengaruh positif dan signifikan terhadap kinerja karyawan. Panggiki, Lumanauw, dan Lumintang (2017) juga menyatakan bahwa kerjasama tim berpengaruh positif dan signifikan terhadap kinerja karyawan. Serta penelitian Nainggolan et al (2020) Kerjasama tim berpengaruh terhadap kinerja pegawai

\section{Keterbatasan dan Agenda Penelitian Mendatang}

Metode pengumpulan data menggunakan kuesioner, sehingga sangat mungkin datanya bersifat subyektif, akan lebih baik bila ditambahkan metode wawancara sehingga hasil penelitian yang diperoleh lebih lengkap. Untuk penelitian selanjutnya, disarankan untuk mencari obyek yang berbeda dan menambah jumlah sampel agar penelitian bisa digeneralisasi. Untuk penelitian selanjutnya, penulis menyarankan agar menambah referensi dan jumlah variabel dalam penelitian, sehingga variabel-variabel lain yang memiliki pengaruh dapat dianalisis pengaruhnya.

\section{Kesimpulan}

Berdasarkan hasil penelitian maka kesimpulan dalam penelitian ini adalah terdapat pengaruh positif dan signifikan kerjasama tim terhadap kinerja karyawan PT. Lion Superindo hal tersebut dapat dibuktikan dari nilai thitung 7,77 > ttabel 2,01. Hal tersebut menandakan bahwa semakin baik penerapan kerjasama tim yang dilakukan perusahaan maka akan semakin meningkat pula kinerja karyawan pada PT. Lion Superindo. Besarnya pengaruh kerjasama tim terhadap kinerja karyawan PT. Lion Superindo sebesar 57,30\%. Tingkat kekuatan hubungan kerjasama tim terhadap kinerja karyawan PT. Lion Superindo sebesar 0,757 artinya tingkat hubungan yang kuat.

\section{Daftar Pustaka}

Arikunto, S. (2015). Prosedur Penelitian Suatu Pendekatan Praktik, Jakarta: Rineka. Cipta.

Fahmi, I. (2017). Manajemen Sumber Daya Manusia. Bandung : Alfabeta.

Hasibuan, M. S. P. (2017). Manajemen Sumber Daya Manusia. Jakarta: PT Bumi Aksara.

Mangkunegara, A.P. (2017). Manajemen Sumber Daya Manusia Perusahaan. Bandung: PT. Remaja Rosdakarya.

Nainggolan, N. T., Lie, D., \& Nainggolan, L. E. (2020). Pengaruh kerjasama tim terhadap kepuasan kerja yang berdampak pada kinerja Pegawai UPT SDA Bah Bolon Dinas Sumber Daya Air Cipta Karya dan Tata Ruang Provinsi Sumatera Utara. Al Tijarah, 6(3), 181-192. 
Nurhayati, R., \& Suprapti, S. (2019). Kinerja Pegawai Dilihat Dari Kemampuan Kerja, Disiplin Kerja Dan Team Work Pada Pegawai Dinas Kesehatan Kabupaten Pemalang. Serat Actiya Jurnal Ilmiah UNTAG Semarang, 8(1), 41-50.

Panggiki, A. C., Lumanauw, B., \& Lumintang, G. G. (2017). Pengaruh Kompensasi, Kerjasama Tim Dan Kepuasan Kerja Terhadap Kinerja Karyawan Pada Ajb Bumiputera 1912 Cabang Sam Ratulangi. Jurnal EMBA: Jurnal Riset Ekonomi, Manajemen, Bisnis Dan Akuntansi, 5(3), 3018-3027. https://doi.org/10.35794/emba.v5i3.17302.

Robbins, S. P., \& Coulter, M. (2016). Manajemen, Jilid 1 Edisi 13, Jakarta: Erlangga.

Sibarani, E. M. (2018). Pengaruh Kerjasama Tim, Kreativitas Dan Budaya Organisasi Terhadap Kinerja Karyawan Pt. Telekomunikasi Indonesia (Telkom) Tbk, Kantor Regional I Medan. Skripsi, Universitas Sumatera Utara Medan.

Sugiyono. (2017). Metode Penelitian Kuantitatif, Kualitatif, dan R\&D. Bandung: Alfabeta.

Susanti, A.A Dwi widyani, dan N. M. S. U. (2017). Pengaruh Keterlibatan Kerja Karyawan, Loyalitas Kerja Dan Kerjasama Tim Terhadap Kinerja Karyawan CV. Sanitary Bali Pinangsia. Jurnal Emas, 2(2), 224-234. https://ejournal.unmas.ac.id/index.php/emas/article/view/1742. 